Article

\title{
Seeding Rates and Productivity of Broadcast Interseeded Cover Crops
}

\author{
Katja Koehler-Cole ${ }^{*}+{ }^{\dagger}$ and Roger W. Elmore ${ }^{\dagger}$ \\ Department of Agronomy \& Horticulture, University of Nebraska-Lincoln, Lincoln, NE 68583, USA; \\ roger.elmore@unl.edu \\ * Correspondence: kkoehlercole2@unl.edu \\ + Both authors contributed equally to this work.
}

Received: 20 October 2020; Accepted: 3 November 2020; Published: 6 November 2020

\begin{abstract}
Broadcast interseeding cover crops into corn (Zea mays L.) and soybean (Glycine max (L.) Merr.) instead of drill-planting after harvest extends the cover crop season and improves productivity, but establishment can be insufficient. Our objectives were to find broadcast seeding rates that result in maximum spring biomass and $\mathrm{N}$ uptake. We tested cereal rye (Secale cereale $\mathrm{L}$.) and hairy vetch (Vicia villosa Roth) in south-central and eastern Nebraska in 2016-2017 and 2017-2018. Seeding rates for rye were 341,512 , and 682 seeds $\cdot \mathrm{m}^{-2}$, and 119,178 , and 238 seeds $\cdot \mathrm{m}^{-2}$ for vetch. We broadcast in late September and terminated by early May. Fall emergence was between 3 and $54 \%$ of broadcast seeds, and greater for vetch. When broadcast into corn, rye spring biomass was $1472 \mathrm{~kg} \cdot \mathrm{ha}^{-1}$ with $\mathrm{N}$ uptake of $38 \mathrm{~kg} \cdot \mathrm{ha}^{-1}$. Vetch biomass was $361 \mathrm{~kg} \cdot \mathrm{ha}^{-1}$ with $13 \mathrm{~kg} \cdot \mathrm{ha}^{-1} \mathrm{~N}$ uptake. In soybean, rye produced $2318 \mathrm{~kg} \cdot \mathrm{ha}^{-1}$ with $59 \mathrm{~kg} \mathrm{~N} \cdot \mathrm{ha}^{-1}$ and vetch produced $535 \mathrm{~kg} \cdot \mathrm{ha}^{-1}$ with $21 \mathrm{~kg} \mathrm{~N} \cdot \mathrm{ha}^{-1}$. Higher seeding rates increased biomass and $\mathrm{N}$ uptake only for rye broadcast into corn. Year and site effects and possibly differences in main crops influenced cover crop productivity.
\end{abstract}

Keywords: broadcasting; interseeding; cover crops; seeding rates; cereal rye; hairy vetch

\section{Introduction}

For cover crops to improve soil health and fulfill species-specific functions, high productivity is essential and is commonly measured as the amount of biomass produced by the cover crop at its termination time. Biomass production is tied to the prevention of soil nitrate leaching, an important function of grass cover crops such as cereal rye (Secale cereale L.) (from here on rye). Cover crops with greater biomass are more effective at suppressing weeds, preventing erosion, and adding organic carbon to the soil [1,2]. In legume cover crops, such as hairy vetch (Vicia villosa Roth) (from here on vetch), high biomass production is associated with their ability to provide $\mathrm{N}$ to a subsequent crop $[1,3]$. Cover crop biomass characteristics, such as its biomass $\mathrm{N}$ concentration and carbon-to-nitrogen ratio, influence biomass decomposition [4] and can help stabilize soil $\mathrm{N}$ [5].

In corn (Zea mays L.) and soybean (Glycine max (L.) Merr.) cropping systems in the western Corn Belt, the growing season is often too short to establish cover crops after corn and soybean harvest. Instead, cover crops can be established in late summer into maturing corn and soybean stands by broadcasting with an airplane or high-clearance interseeding equipment. Planting by broadcasting before corn or soybean harvest has several advantages: it is less labor-intensive because more acreage can be planted in the same time, it may be cheaper than drilling, especially if carried out with high-clearance equipment, and it shifts the workload away from the busy time of the harvest season [6]. The earlier establishment allows cover crops to capture more growing degree days and precipitation than seeding after corn or soybean harvest, resulting in greater biomass for broadcast interseeded than drilled cover crops in most site years in Nebraska [7]. A Nebraska survey found that approximately 
$27 \%$ of farmers that use cover crops plant them before corn or soybean harvest, typically by aerial interseeding [8].

Broadcast seeds encounter different growing conditions than drilled seeds which influences their germination and productivity. Seeds on the soil surface are vulnerable to abiotic and biotic factors, most notably the availability of water that limits germination of seeds but also seed predation $[9,10]$. As a result, stand counts of broadcast interseeded cover crops are typically lower and more variable than when planting by drilling where seeds are deposited into the soil at a uniform depth [11]. In addition, interseeded cover crops face low-light conditions [12], restricting photosynthesis and subsequently growth $[13,14]$. Some species are more shade-tolerant, for example, vetch has been reported to be more productive than rye while growing in the corn canopy [15]. Selecting higher seeding rates may be necessary for sufficient biomass production of broadcast interseeded cover crops but will increase seed costs, a major component of the cost of cover cropping [6]. Recommended seeding rates for broadcasting rye range from 67 to $107 \mathrm{~kg} \cdot \mathrm{ha}^{-1}$ and for vetch from 22 to $44 \mathrm{~kg} \cdot \mathrm{ha}^{-1}$ [16-18]. Identifying optimum seeding rates for cover crops can improve cover crop productivity and possibly reduce seed costs.

To our knowledge, recommendations for cover crop species or seeding rates are not different whether interseeding into corn or soybean. However, these two crops differ in the amount of light transmitted to the soil surface and the amount of residue present, especially in no-till systems common across the western Corn Belt. Light transmission increases as the main crop matures, drops its leaves, and is harvested, which typically occurs sooner in soybean than in corn, thus potentially benefitting cover crops broadcast interseeded into soybean. In no-till corn, large quantities of residue including standing stalks remain after harvest which lower wind speed and soil evaporation, and moderate soil temperatures $[19,20]$. These modifications possibly protect cover crops during the harsh winters of the western Corn Belt, which in turn could increase winter survival and spring productivity.

With this research project, we want to determine the productivity of hairy vetch and cereal rye cover crops when broadcast interseeded into maturing corn and soybean stands and whether their productivity can be increased with higher seeding rates. We hypothesize that in both corn and soybean, (1) similar proportions of rye and vetch seed will emerge; (2) rye will have more biomass, lower $\mathrm{N}$ concentration, greater $\mathrm{N}$ uptake, and greater $\mathrm{C} / \mathrm{N}$ ratios than vetch; and (3) increasing seeding rates will increase stand counts, biomass production, and $\mathrm{N}$ uptake of rye and vetch cover crops. The information gained from this study can provide valuable management information for farmers and ultimately lead to improved success with cover crops.

\section{Materials and Methods}

The experiments were carried out in 2016-2017 (year 1) and 2017-2018 (year 2) at two sites in Nebraska: South-Central Agricultural Laboratory $\left(40^{\circ} 34^{\prime} \mathrm{N}, 98^{\circ} 08^{\prime} \mathrm{W}\right.$; altitude $\left.552 \mathrm{~m}\right)$ near Clay Center and Eastern Nebraska Research and Extension Center $\left(41^{\circ} 09^{\prime} \mathrm{N}, 96^{\circ} 24^{\prime} \mathrm{W}\right.$; altitude $\left.347 \mathrm{~m}\right)$ near Mead. Clay Center is in the transition zone between a sub-humid and semi-arid climate with strong winds (USDA hardiness zone 5b) and Hastings silt loam soils (fine, montmorillonitic, mesic Udic Argiustoll). Mead is in the sub-humid zone (USDA hardiness zone $5 b$ ) and has Sharpsburg silty clay loam (fine, montmorillonitic, mesic Typic Argiudolls). Both sites were in corn-soybean rotations and were not tilled. The site at Clay Center received weekly irrigation between June and August, but the site at Mead was rainfed. At each site, there were two fields in year 1: one field where the previous crop had been soybean was planted to field corn (conventional, traited hybrids) and an adjacent field where the previous crop had been corn was planted to soybean (conventional, traited varieties) (Table 1). In year 2, soybean was planted in the year 1 corn field and corn in the year 1 soybean field. At Clay Center, corn with a relative maturity (RM) of 107 days (year 1) and 109 days (year 2) was planted at 84,000 seeds ha ${ }^{-1}$ and soybean (maturity group 2.4 in both years) was planted at 372,000 seeds ha ${ }^{-1}$ in $0.76 \mathrm{~m}$ rows. At Mead, corn (RM 111 days) was planted at 65,000 seeds ha ${ }^{-1}$ and soybean (maturity group 3.0) was planted at 445,000 seeds $\mathrm{ha}^{-1}$ in $0.76 \mathrm{~m}$ rows. Corn planting populations were within the 
typical range for this region, with rainfed sites at the lower end of the range [21,22]. Soybean planting populations were close to the recommended rate for the western Corn Belt of 350,000 plants ha ${ }^{-1}$ [23], but higher at Mead because soybean was planted later there. Tillage was not implemented at either site except for one pass with a disk before corn and soybean planting at Mead in year 2.

Table 1. Field operations and sampling schedule for each site (Clay Center and Mead) in year 1 (2016-2017) and year 2 (2017-2018).

\begin{tabular}{lcccc}
\hline & \multicolumn{2}{c}{ Clay Center } & \multicolumn{2}{c}{ Mead } \\
\hline Activities & Corn & Soybean & Corn & Soybean \\
\hline Year 1 & & & & \\
Plant main crop & 12 May 2016 & 13 May 2016 & 3 June 2016 & 9 June 2016 \\
Plant cover crop & 20 September & 23 September & 21 September & 21 September \\
Harvest main crop & 18 October & 19 September & 1 November & 7 November \\
Count cover crop & 1 December & 1 December & na ${ }^{\dagger}$ & na \\
Biomass cover crop & 4 May 2017 & 4 May 2017 & 8 May 2017 & 8 May 2017 \\
Year 2 & & & & \\
Plant main crop & 8 May 2017 & 12 May 2017 & 12 May 2017 & 31 May 2017 \\
Plant cover crop & 22 September & 14-19 September & 19 September & 21 September \\
Harvest main crop & late October & mid-October & late October & 6 November \\
Count cover crop & 20 November & 20 November & 30 November & 30 November \\
Biomass cover crop & 4 May 2018 & 8 May 2018 & 9 May 2018 & 8 May 2018 \\
\hline
\end{tabular}

${ }^{\dagger}$ na, data not taken.

For the experiment, randomized complete blocks with four replications were set up in every field. Treatments were arranged as a factorial with two cover crops (rye and vetch) and three seeding rates (Table 2). The seeding rates represent low, medium, and high seeding rates for each species and were adjusted for pure, live seed (PLS) [16-18]. Plots measured 6.1 (eight corn or soybean rows, respectively) by $9.1 \mathrm{~m}$ at Clay Center and 4.6 (six corn or soybean rows, respectively) by $9.1 \mathrm{~m}$ at Mead. Plots received the same cover crop by seeding rate treatment each year. Cover crops were planted in September by spreading seed by hand in soybean and corn stands (Table 1). Seed was not incorporated into the soil. At the time of cover crop planting, corn development stage was R5 and soybean development stage was R7 or R8 [24,25].

Table 2. Cultivar, seeding rates in $\mathrm{kg} \cdot \mathrm{ha} \mathrm{a}^{-1}$ and pure live seeds $\mathrm{m}^{-2}$ (PLS), and seed cost in USD ha ${ }^{-1}$ for cereal rye (rye) and hairy vetch (vetch) cover crops.

\begin{tabular}{|c|c|c|c|c|}
\hline \multirow[t]{2}{*}{ Cover Crop } & \multicolumn{3}{|c|}{ Cover Crop Seeding Rate } & \multirow{2}{*}{$\begin{array}{l}\text { Seed Cost } \\
\text { USD ha }^{-1}\end{array}$} \\
\hline & & $\mathrm{kg} \cdot \mathrm{ha}^{-1}$ & PLS $\mathbf{m}^{-2}$ & \\
\hline \multirow[t]{3}{*}{ Rye "Elbon" } & Low & 67 & 341 & 30.82 \\
\hline & Medium & 101 & 512 & 46.46 \\
\hline & High & 135 & 682 & 62.10 \\
\hline \multirow[t]{3}{*}{ Vetch "MT vetch" } & Low & 45 & 119 & 198.45 \\
\hline & Medium & 67 & 178 & 295.47 \\
\hline & High & 90 & 238 & 396.90 \\
\hline
\end{tabular}

Cover crop stand counts were carried out approximately 70 days after planting (DAP) (Table 1), once killing freezes $\left(-4.4^{\circ} \mathrm{C}\right)$ had occurred. In year 1 , cover crops were not counted at Mead because they were frozen to the ground. Two 0.3 by $1.5 \mathrm{~m}$ frames were placed randomly in each plot and all cover crop plants within the frames were counted. Stand counts were used to calculate the proportion of planted seeds that resulted in live plants $70 \mathrm{DAP}$, which was given as a percentage. In the spring, two 0.3 by $1.5 \mathrm{~m}$ frames were again placed randomly in each plot and cover crop biomass was cut at surface level (main crop residue and/or weeds were not included). Biomass was dried at $60^{\circ} \mathrm{C}$ to constant weight for dry matter and weighed. Subsamples of the dried cover crop biomass were ground 
with a Wiley Mill and passed through a $1 \mathrm{~mm}$ sieve. Subsamples were then analyzed for carbon and nitrogen concentration by elemental combustion on a LECO TruMach Nitrogen/Carbon Combustion Analyzer (LECO Corporation, St. Joseph, MI, USA) according to methods described by Miller et al. [26]. Carbon and nitrogen concentrations were used to determine the total amount of $\mathrm{N} \mathrm{in} \mathrm{kg \cdot ha-1}$ contained in the cover crop biomass and the carbon to nitrogen $(\mathrm{C} / \mathrm{N})$ ratio. Temperatures and precipitation data for each site year were obtained from the High Plains Regional Climate Center, from the Harvard station near Clay Center and the Ithaca station near Mead. We calculated fall precipitation as the sum of precipitation from DAP to 30 November. Winter and spring precipitation was the amount of precipitation from 1 December to the date of biomass harvest for each treatment in each site year. Long-term average precipitation and temperature were calculated from weather data from 1982 to 2019 at the Harvard station and 1981 to 2019 at the Ithaca station. To calculate growing degree days (GDD), a base temperature of $4{ }^{\circ} \mathrm{C}$ was used for vetch [27] and $0{ }^{\circ} \mathrm{C}$ was used for rye [28], resulting in the following formulas:

$$
\begin{array}{lcc}
\text { For vetch: } & \mathrm{GDD}=\left(\left(\mathrm{T}_{\text {high }}-\mathrm{T}_{\text {low }}\right) / 2\right)-4{ }^{\circ} \mathrm{C} & \mathrm{GDD} \geq 0 \\
\text { For rye: } & \mathrm{GDD}=\left(\left(\mathrm{T}_{\text {high }}-\mathrm{T}_{\text {low }}\right) / 2\right) & \mathrm{GDD} \geq 0
\end{array}
$$

where $\mathrm{T}_{\text {high }}$ is the daily high temperature and $\mathrm{T}_{\text {low }}$ is the daily low temperature. Total accumulated growing degrees were the sum of all GDD from cover crop DAP to cover crop biomass harvest. Data were analyzed using the PROC GLIMMIX procedure of SAS 9.4 (SAS Inst., Cary, NC, USA). Separate ANOVAs were carried out for cover crops broadcast interseeded into corn and soybean. Treatment effects were compared with the LSmeans statement and were considered significant at the $\alpha=0.05$ level. Fall cover crop stand counts (in plants $\mathrm{m}^{-}$) and cover crop emergence (in percent) were compared separately by site, because data were not available for all site years. At Mead, where only year 2 data were available, species, rate, and their interaction were fixed effects and block was a random effect. At Clay Center, where data were collected in both years, species, rate, the year by species, year by rate, species by rate, and year by species by rate interactions were fixed effects and block and its interaction with year was a random effect. Where rate was significant, the estimate statement was used to test for possible linear and quadratic effects. Linear and quadratic models can be used to explain many agronomic relationships [1], for example, the response of plant biomass and yield to increasing plant seeding rates [22]. The quadratic relationship was never significant and thus only the linear relationship, where it was significant, was discussed. In the analysis of biomass parameters (biomass, biomass $\mathrm{N}$ concentration, $\mathrm{N}$ uptake, and $\mathrm{C} / \mathrm{N}$ ratio), cover crop species, seeding rate, and their interaction were fixed factors. The two-way and three-way interactions of species, rate, and year and the two-way and three-way interactions of species, rate, and site were also considered fixed factors. The random factors were block and its interaction with year and site. Where rate effects were significant, they were tested for linear or quadratic effect using the estimate statement, and the resulting $p$-values are shown in the text.

\section{Results}

\subsection{Weather}

Long-term average fall precipitation at Clay Center is $102 \mathrm{~mm}$ and at Mead $115 \mathrm{~mm}$. Long-term average winter and spring precipitation at Clay Center is also lower than at Mead, 187 and $211 \mathrm{~mm}$, respectively. Long-term average fall temperature is slightly cooler at Clay Center $\left(8.1^{\circ} \mathrm{C}\right)$ than at Mead $\left(8.5^{\circ} \mathrm{C}\right)$ and long-term average winter and spring temperatures are similar at both sites $(1.6$ and $1.5^{\circ} \mathrm{C}$, respectively). Long-term average GDD accumulation between 21 September and 8 May is similar at both sites: 1113 for rye and 626 for vetch at Clay Center, and 1162 for rye and 672 for vetch at Mead. At Clay Center in year 1, fall precipitation was $43 \mathrm{~mm}$ and winter and spring precipitation was $159 \mathrm{~mm}$ (Figure 1). Fall temperature was $11.6^{\circ} \mathrm{C}$ and winter and spring temperature was $2.5^{\circ} \mathrm{C}$. 
From DAP to cover crop biomass sampling, rye accumulated 1627 GDD and vetch 1012 GDD. In year 2 , fall precipitation for cover crops in soybean was higher $(152 \mathrm{~mm})$ than for those planted in corn $(131 \mathrm{~mm})$ because they were planted about a week later. Winter and spring precipitation in year 2 was only $51 \mathrm{~mm}$. Fall temperatures were lower than in year $1\left(10.5^{\circ} \mathrm{C}\right.$ in soybean, $9.3^{\circ} \mathrm{C}$ in corn) and winter and spring temperatures were very low $\left(0.3^{\circ} \mathrm{C}\right)$. The unusually dry and cold spring with daily temperatures below freezing occurring until mid-April resulted in low GDD accumulation for cover crops (1415 for rye and 860 for vetch).

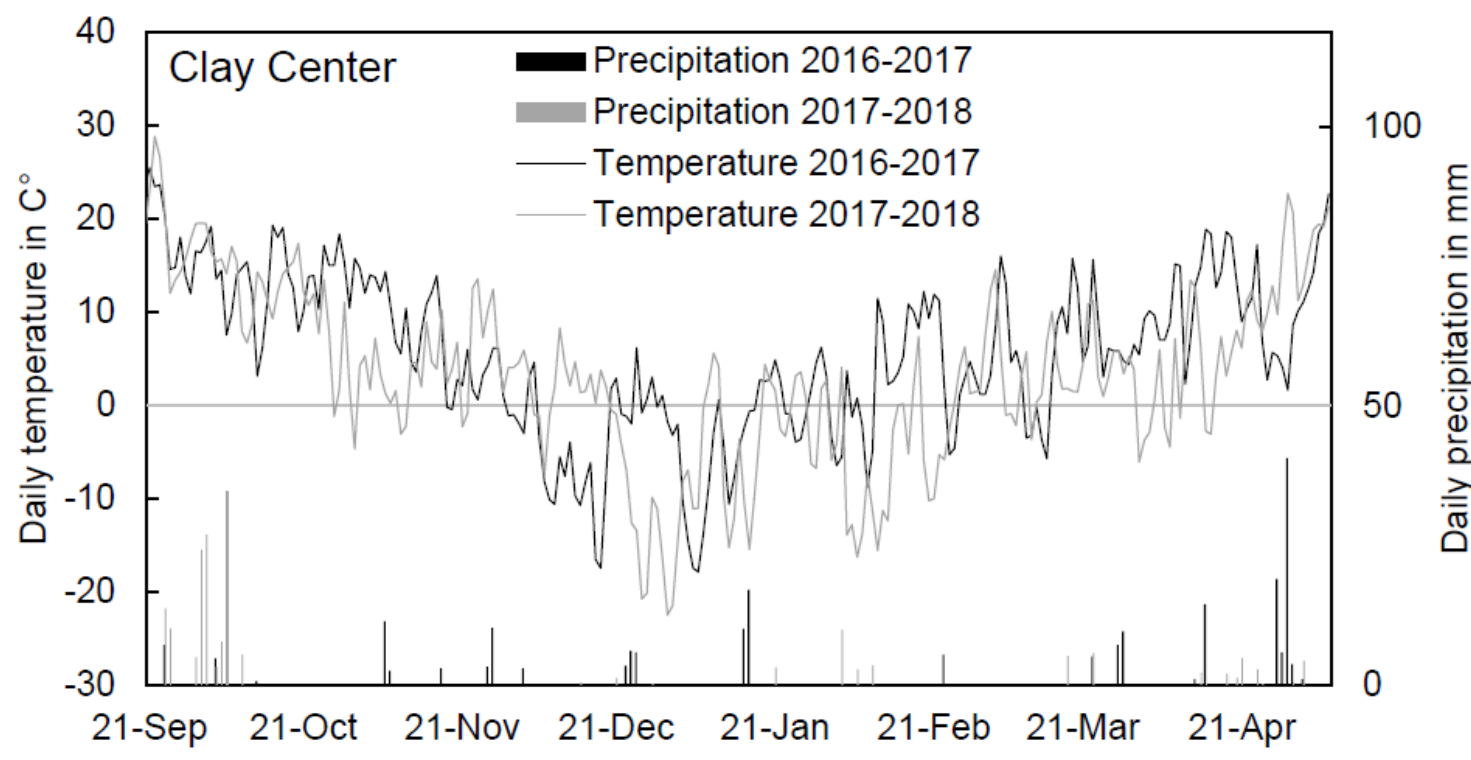

Figure 1. Daily average temperature (left axis, line graph) and precipitation (right axis, bar graph) from cover crop planting to cover crop harvest for year 1 (September 2016 to May 2017) and year 2 (September 2017 to May 2018) at Clay Center.

At Mead in year 1, fall precipitation was $67 \mathrm{~mm}$, winter and spring precipitation was $209 \mathrm{~mm}$, fall temperature was $11.7^{\circ} \mathrm{C}$, and winter and spring temperature was $2.9^{\circ} \mathrm{C}$ (Figure 2). Rye accumulated 1564 GDD and vetch 970 GDD by the time they were harvested. At that site in year 2, fall precipitation was higher $(187 \mathrm{~mm})$ but winter and spring precipitation was lower $(86 \mathrm{~mm})$ and both fall and winter and spring temperatures were lower $\left(10\right.$ and $0.2^{\circ} \mathrm{C}$, respectively) than in year 2 . As in Clay Center, the long cold period in the spring resulted in less GDD accumulation than in year 1, with 1350 GDD for rye and 819 GDD for vetch. 


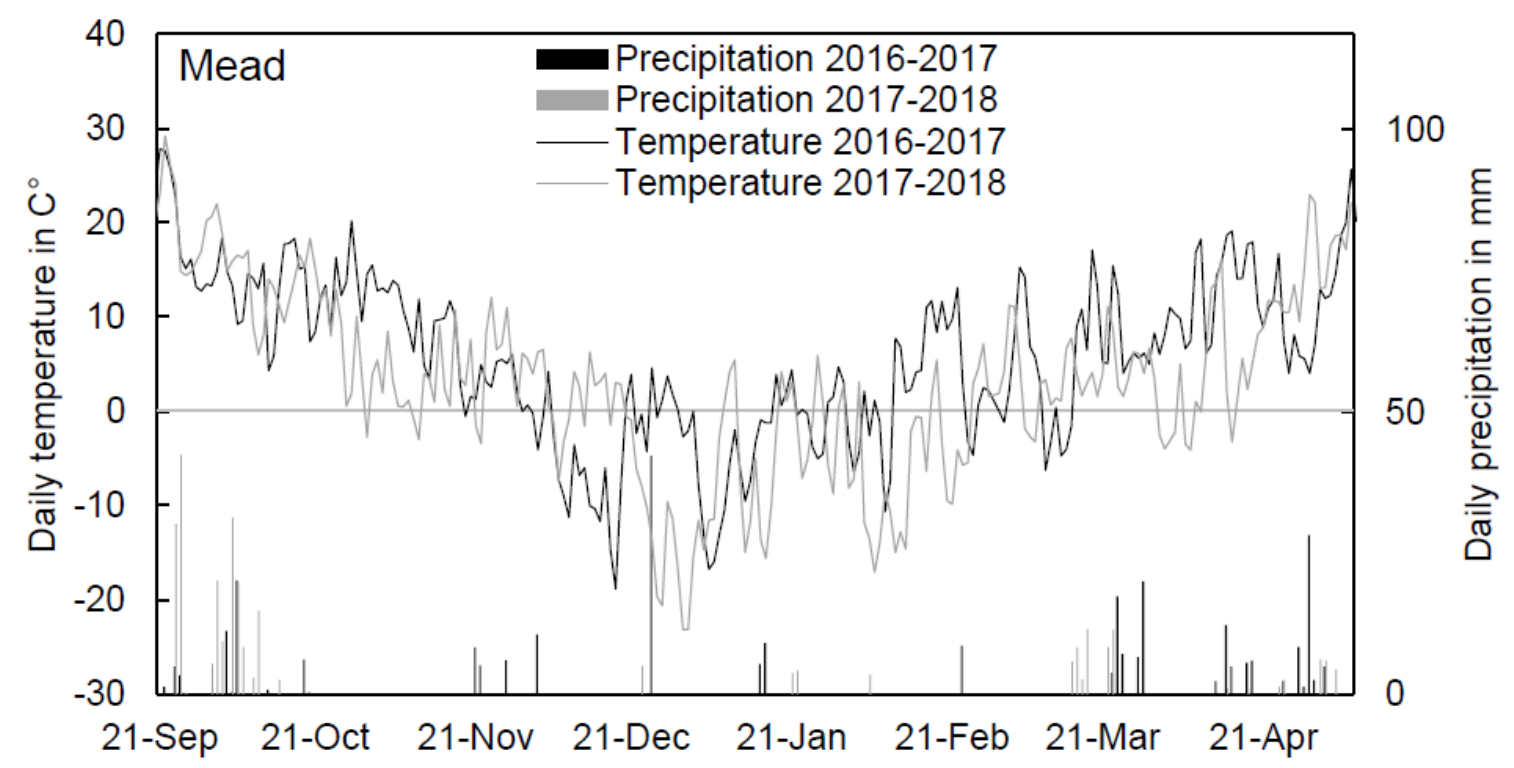

Figure 2. Daily average temperature (left axis, line graph) and precipitation (right axis, bar graph) from cover crop planting to cover crop harvest for year 1 (September 2016 to May 2017) and year 2 (September 2017 to May 2018) at Mead.

\subsection{Cover Crops Broadcast Planted into Corn}

Fall stand counts of cover crops planted into corn will be discussed separately by site, because stand counts were not available for all site years. At Clay Center, plants were counted in both year 1 (2016/2017) and year 2 (2017/2018). Stand counts were influenced by the main effect of seeding rate but not species (Table 3). Increasing the seeding rate increased stand counts linearly $(p=0.001)$. The year by species interaction also influenced plant counts. Rye had the same stand counts in both years, but vetch had greater stand counts in year 2 than in year 1 (2016/2017) (Table 4). The seeding rate impacted the year by species interaction (data not shown). In vetch in year 1, increasing the seeding rate did not increase stand counts $\left(17\right.$ plants $\left.\cdot \mathrm{m}^{-2}\right)$, but in year 2 , the high seeding rate had 43 plants $\cdot \mathrm{m}^{-2}, 17$ plants $\cdot \mathrm{m}^{-2}$ more than the low seeding rate. Rye, on the other hand, responded with more variability to increases in seeding rates. In year 1 , rye at the lowest seeding rate had only 3 plants $\mathrm{m}^{-2}$, whereas at the highest seeding rate, it had 52 plants $\mathrm{m}^{-2}$. In year 2 , rye stand counts were similar for all seeding rates and were 24 plants $\mathrm{m}^{-2}$. At Mead, plants were only counted in year 2 . There were 121 rye.plants $\mathrm{m}^{-2}$, 28 plants $\mathrm{m}^{-2}$ more than in vetch (Table 4$)$. Stand counts increased linearly with seeding rate $(p=0.002)$. The number of seeds contained in the low, medium, and high seeding rates is different for rye and vetch (Table 2), so the percentage of seeds that emerged may be a better indicator of seed establishment than stand counts. At both sites, emergence was greater for vetch than for rye (Tables 3 and 4). At Mead, about $54 \%$ of vetch seed emerged, but only $24 \%$ of rye seed. At Clay Center, $15 \%$ of vetch and $5 \%$ of rye seed resulted in plants. At that site, year 2 had almost double the vetch emergence than year 1, but rye emergence was the same across years. Cover crop species and its interaction with year or site almost always influenced cover crop biomass and biomass $\mathrm{N}$ parameters (Table 5). Overall, rye produced $1472 \mathrm{~kg} \cdot \mathrm{ha}^{-1}$ and vetch produced $361 \mathrm{~kg} \cdot \mathrm{ha}^{-1}$, but the greater value for rye was due to the productive rye cover crop in 2017 that had a biomass of $2679 \mathrm{~kg} \cdot \mathrm{ha}^{-1}$. On the other hand, rye biomass in 2018 was a tenth of the 2017 biomass, and was similar to vetch biomass (Table 6). Cover crop biomass was also influenced by the main effects of seeding rate and the species by seeding rate interaction (Table 6 ). Increasing the seeding rate of rye increased rye biomass linearly $(p=0.0005$, data not shown) but vetch biomass did not respond to increasing seeding rates $(p=0.1497)$. The the three-way interaction of year by species by rate also impacted biomass (data now shown). Increasing the seeding rate from low to medium increased cover crop productivity, in large part due to rye's greater biomass values in 2017. In that year, rye planted at the medium seeding rate had $3047 \mathrm{~kg} \cdot \mathrm{ha}^{-1}, 80 \%$ more biomass than rye 
planted at the low seeding rate which had $1692 \mathrm{~kg} \cdot \mathrm{ha}^{-1}$ (data not shown). Increasing the seeding rate from medium to high resulted in $3298 \mathrm{~kg} \cdot \mathrm{ha}^{-1}$, but this was not a significant difference. Cover crop $\mathrm{N}$ concentration (in $\mathrm{g} \cdot \mathrm{kg}^{-1}$ ) was lowest in rye at Mead $\left(21 \mathrm{~g} \cdot \mathrm{kg}^{-1}\right)$ but vetch at Mead and both cover crops at Clay Center had N concentrations that were almost twice as high (Table 5). Both species had lower $\mathrm{N}$ concentrations in year 1 than in year 2, but year 1 vetch and year 2 rye were similar. Nitrogen uptake $\left(\mathrm{kg} \mathrm{N} \cdot \mathrm{ha}^{-1}\right)$ was greater for rye than vetch at each site, with a maximum of $58 \mathrm{~kg} \mathrm{~N} \cdot \mathrm{ha}{ }^{-1}$ at Clay Center, but rye at Mead had similar $\mathrm{N}$ uptake to vetch at Clay Center. Across sites, rye in year 1 had the greatest $\mathrm{N}$ uptake $\left(65 \mathrm{~kg} \mathrm{~N} \cdot \mathrm{ha}^{-1}\right.$ ), whereas the cover crops in the other years had similar $\mathrm{N}$ uptake. Increasing seeding rates from low to medium or high increased $\mathrm{N}$ uptake and this was a linear effect ( $p=0.005$, data not shown). Seeding rate also interacted with year to influence $\mathrm{N}$ uptake. In year 1 , the low seeding rate had $31 \mathrm{~kg} \mathrm{~N} \cdot \mathrm{ha}^{-1}$, less than the medium and high seeding rates which had 48 and $52 \mathrm{~kg} \mathrm{~N} \cdot \mathrm{ha}^{-1}$, respectively. In year 2, all seeding rates resulted in similar N uptake, between 7 and $9 \mathrm{~kg} \mathrm{~N} \cdot \mathrm{ha}^{-1}$. Rye biomass in year 1 had a greater $\mathrm{C} / \mathrm{N}$ ratio than all other cover crops (Table 6). Across years, biomass $\mathrm{C} / \mathrm{N}$ ratios were greatest for rye at Mead which had a $\mathrm{C} / \mathrm{N}$ ratio of 22 , whereas rye at Clay Center, and vetch at both sites had $\mathrm{C} / \mathrm{N}$ ratios of 12:1 and 11:1, respectively. 
Table 3. Source of variation (cover crop species, year, and cover crop seeding rate), degrees of freedom (d.f.) and $p$-values for cover crop stand counts, and the percentage of planted cover crops seeds that emerged. Seeds were broadcast interseeded into corn and soybean at two sites (Clay Center and Mead).

\begin{tabular}{|c|c|c|c|c|c|c|c|c|c|}
\hline \multirow{3}{*}{ Source of Variation } & & \multicolumn{4}{|c|}{ Cover Crops Broadcast into Corn } & \multicolumn{4}{|c|}{ Cover Crops Broadcast into Soybean } \\
\hline & \multirow[b]{2}{*}{ d.f. } & \multicolumn{2}{|c|}{ Clay Center } & \multicolumn{2}{|c|}{ Mead * } & \multicolumn{2}{|c|}{ Clay Center } & \multicolumn{2}{|c|}{ Mead * } \\
\hline & & Count & Percentage & Count & Percentage & Count & Percentage & Count & Percentage \\
\hline Species & 1 & 0.764 & $<0.001$ & 0.007 & $<0.001$ & 0.576 & $<0.001$ & 0.002 & $<0.001$ \\
\hline Year $\times$ Species & 1 & 0.008 & 0.001 & . & . & $<0.001$ & $<0.001$ & . & . \\
\hline Rate & 2 & $<0.001$ & 0.915 & 0.006 & 0.288 & $<0.001$ & 0.137 & 0.009 & 0.121 \\
\hline Year $\times$ Rate & 2 & 0.051 & 0.117 & . & . & 0.011 & 0.168 & . & . \\
\hline Species $\times$ Rate & 2 & 0.104 & 0.262 & 0.577 & 0.684 & 0.678 & 0.472 & 0.316 & 0.299 \\
\hline Year $\times$ Species $\times$ Rate & 2 & 0.001 & 0.329 & . & . & 0.211 & 0.757 & . & . \\
\hline
\end{tabular}

* Data were only available in year 2 
Table 4. The percentage of seed planted that emerged and the resulting stand counts (in plants $\mathrm{m}$-2) for cereal rye (rye) and hairy vetch (vetch) cover crops, planted into corn and soybean at two sites (Clay Center and Mead). Within a column, means followed by the same letter are not significantly different from each other at a significance level of $\alpha=0.05$.

\begin{tabular}{|c|c|c|c|c|c|c|c|c|}
\hline \multirow{3}{*}{ Treatments } & \multicolumn{4}{|c|}{ Cover Crops Broadcast into Corn } & \multicolumn{4}{|c|}{ Cover Crops Broadcast into Soybean } \\
\hline & \multicolumn{2}{|c|}{ Clay Center } & \multicolumn{2}{|c|}{ Mead * } & \multicolumn{2}{|c|}{ Clay Center } & \multicolumn{2}{|c|}{ Mead * } \\
\hline & Count & Percentage & Count & Percentage & Count & Percentage & Count & Percentage \\
\hline Species & $\mathrm{m}^{-2}$ & $\%$ & $\mathrm{~m}^{-2}$ & $\%$ & $\mathrm{~m}^{-2}$ & $\%$ & $\mathrm{~m}^{-2}$ & $\%$ \\
\hline Rye & 24 & $5 \mathrm{~b}$ & $121 \mathrm{a}$ & $24 \mathrm{~b}$ & 17 & $3 b$ & $106 \mathrm{a}$ & $21 \mathrm{~b}$ \\
\hline Vetch & 25 & $15 \mathrm{a}$ & $93 \mathrm{~b}$ & $54 \mathrm{a}$ & 18 & $10 \mathrm{a}$ & $72 \mathrm{~b}$ & $42 \mathrm{a}$ \\
\hline \multicolumn{9}{|l|}{ Rate } \\
\hline Low & $16 \mathrm{c}$ & 10 & $83 \mathrm{~b}$ & 44 & $9 c$ & 5 & $69 \mathrm{~b}$ & 37 \\
\hline Medium & $24 \mathrm{~b}$ & 9 & $113 \mathrm{a}$ & 41 & $17 \mathrm{~b}$ & 6 & $89 \mathrm{ab}$ & 30 \\
\hline High & $35 a$ & 9 & $125 \mathrm{a}$ & 33 & $27 \mathrm{a}$ & 8 & 109 a & 27 \\
\hline \multicolumn{9}{|c|}{ Species $\times$ Rate } \\
\hline \multicolumn{9}{|l|}{ Rye } \\
\hline Low & 13 & 4 & 95 & 28 & 8 & 2 & 76 & 22 \\
\hline Medium & 21 & 4 & 122 & 24 & 18 & 3 & 107 & 21 \\
\hline High & 39 & 6 & 146 & 21 & 24 & 4 & 133 & 20 \\
\hline \multicolumn{9}{|l|}{ Vetch } \\
\hline Low & 19 & 16 & 71 & 59 & 10 & 8 & 61 & 52 \\
\hline Medium & 27 & 15 & 103 & 58 & 16 & 9 & 70 & 40 \\
\hline High & 31 & 13 & 104 & 44 & 29 & 12 & 84 & 35 \\
\hline \multicolumn{9}{|c|}{ Year $\times$ Species } \\
\hline \multicolumn{9}{|c|}{ Year 1} \\
\hline Rye & $24 \mathrm{bc}$ & $4 c$ & $121 \mathrm{a}$ & $24 \mathrm{~b}$ & $22 \mathrm{~b}$ & $4 \mathrm{~b}$ & $106 \mathrm{a}$ & $21 \mathrm{~b}$ \\
\hline Vetch & $18 \mathrm{c}$ & $10 \mathrm{~b}$ & $93 \mathrm{~b}$ & $54 \mathrm{a}$ & $2 \mathrm{~d}$ & $1 \mathrm{c}$ & $72 \mathrm{~b}$ & $42 \mathrm{a}$ \\
\hline \multicolumn{9}{|l|}{ Year 2} \\
\hline Rye & $24 \mathrm{bc}$ & $5 \mathrm{bc}$ & na & na & $11 \mathrm{~cd}$ & $2 \mathrm{bc}$ & na & na \\
\hline Vetch & $34 \mathrm{a}$ & $19 \mathrm{a}$ & na & na & $35 a$ & $19 a$ & na & na \\
\hline
\end{tabular}

* Data were only available in year 2 . 
Table 5. Source of variation, and degrees of freedom (d.f.) and $p$-values for biomass parameters of cover crops broadcast interseeded into corn and cover crops broadcast interseeded into soybean. Variables were site, year, cover crop species, and cover crop seeding rate. Parameters were biomass (DM, $\mathrm{kg}^{-h a^{-1}}$ ), biomass $\mathrm{N}$ concentration $\left(\mathrm{N}\right.$, in $\left.\mathrm{g} \cdot \mathrm{kg}^{-1}\right)$, biomass $\mathrm{N}$ uptake (in $\mathrm{kg} \cdot \mathrm{ha}^{-1}$ ), and the biomass carbon to nitrogen ratio $(\mathrm{C} / \mathrm{N})$.

\begin{tabular}{|c|c|c|c|c|c|c|c|c|c|}
\hline \multirow[b]{2}{*}{ Source of Variation } & \multirow[b]{2}{*}{ D.f. } & \multicolumn{4}{|c|}{ Cover Crops Broadcast into Corn } & \multicolumn{4}{|c|}{ Cover Crops Broadcast into Soybean } \\
\hline & & DM & $\mathbf{N}$ & N Uptake & $\mathbf{C} / \mathbf{N}$ & DM & $\mathbf{N}$ & N Uptake & $\mathrm{C} / \mathrm{N}$ \\
\hline Site & 1 & 0.487 & 0.121 & 0.437 & 0.099 & 0.134 & 0.295 & 0.118 & 0.078 \\
\hline Year & 1 & 0.198 & 0.123 & 0.350 & 0.071 & 0.125 & 0.612 & 0.078 & 0.153 \\
\hline Species & 1 & $<0.001$ & $<0.001$ & $<0.001$ & $<0.001$ & $<0.001$ & $<0.001$ & $<0.001$ & $<0.001$ \\
\hline Site $\times$ Species & 1 & 0.058 & $<0.001$ & $<0.001$ & $<0.001$ & $<0.001$ & $<0.001$ & 0.666 & 0.600 \\
\hline Rate & 2 & $<0.001$ & 0.869 & 0.006 & 0.922 & 0.783 & 0.135 & 0.963 & 0.709 \\
\hline Site $\times$ Rate & 2 & 0.292 & 0.575 & 0.250 & 0.980 & 0.114 & 0.070 & 0.458 & 0.926 \\
\hline Species $\times$ Rate & 2 & 0.003 & 0.096 & 0.087 & 0.434 & 0.081 & 0.270 & 0.122 & 0.700 \\
\hline Site $\times$ Species $\times$ Rate & 2 & 0.739 & 0.846 & 0.394 & 0.925 & 0.156 & 0.854 & 0.404 & 0.717 \\
\hline Year $\times$ Species & 1 & $<0.001$ & $<0.001$ & $<0.001$ & $<0.001$ & $<0.001$ & 0.002 & $<0.001$ & 0.053 \\
\hline Year $\times$ Rate & 2 & 0.001 & 0.043 & 0.037 & 0.650 & 0.207 & 0.493 & 0.283 & 0.922 \\
\hline Year $\times$ Species $\times$ Rate & 2 & 0.005 & 0.944 & 0.087 & 0.818 & 0.490 & 0.511 & 0.634 & 0.824 \\
\hline
\end{tabular}


Table 6. Biomass parameter means of cover crops broadcast planted into corn and of cover crops broadcast planted into soybean. The parameters were biomass (DM, in $\mathrm{kg}^{\circ} \mathrm{ha}^{-1}$ ), biomass $\mathrm{N}$ concentration $\left(\mathrm{N}_{\text {conc }}\right.$, in $\left.\mathrm{g} \cdot \mathrm{kg}^{-1}\right)$, biomass $\mathrm{N}$ uptake $\left(\mathrm{N}\right.$, in $\left.\mathrm{kg} \cdot \mathrm{ha}^{-1}\right)$, and the biomass carbon to nitrogen ratio $(\mathrm{C} / \mathrm{N})$. Within a column, means followed by the same letter are not significantly different from each other at a significance level of $\alpha=0.05$. Where rate was significant, it was tested for linear and quadratic effects with results shown in the text.

\begin{tabular}{|c|c|c|c|c|c|c|c|c|}
\hline \multirow[b]{2}{*}{ Treatments } & \multicolumn{4}{|c|}{ Cover Crops Broadcast into Corn } & \multicolumn{4}{|c|}{ Cover Crops Broadcast into Soybean } \\
\hline & DM & $\mathbf{N}_{\text {conc }}$ & $\mathbf{N}$ & $\mathrm{C} / \mathrm{N}$ & DM & $\mathbf{N}_{\text {conc }}$ & $\mathbf{N}$ & $\mathbf{C} / \mathbf{N}$ \\
\hline Species & $\mathrm{kg} \cdot \mathrm{ha}^{-1}$ & $\mathrm{~g} \mathrm{~kg}^{-1}$ & $\mathrm{~kg} \cdot \mathrm{ha}^{-1}$ & & $\mathrm{~kg} \cdot \mathrm{ha}^{-1}$ & $\mathrm{~g} \mathrm{~kg}^{-1}$ & $\mathrm{~kg} \cdot \mathrm{ha}^{-1}$ & \\
\hline Rye & $1472 \mathrm{a}$ & $31 \mathrm{~b}$ & $38 \mathrm{a}$ & $17 \mathrm{a}$ & 2318 a & $27 \mathrm{~b}$ & $59 \mathrm{a}$ & $17 \mathrm{a}$ \\
\hline Vetch & $361 \mathrm{~b}$ & $40 \mathrm{a}$ & $13 \mathrm{~b}$ & $11 \mathrm{~b}$ & $535 \mathrm{~b}$ & $38 \mathrm{a}$ & $21 \mathrm{~b}$ & $8 \mathrm{~b}$ \\
\hline \multicolumn{9}{|l|}{ Rate } \\
\hline Low & $620 \mathrm{~b}$ & 36 & $19 \mathrm{~b}$ & 14 & 1452 & 34 & 41 & 12 \\
\hline Medium & $1020 \mathrm{a}$ & 36 & $28 \mathrm{a}$ & 14 & 1370 & 32 & 9 & 12 \\
\hline High & $1110 \mathrm{a}$ & 35 & $30 \mathrm{a}$ & 14 & 1458 & 32 & 39 & 13 \\
\hline \multicolumn{9}{|c|}{ Species by Rate } \\
\hline \multicolumn{9}{|c|}{ Rye } \\
\hline Low & $946 \mathrm{~b}$ & 32 & 27 & 17 & 2484 & 29 & 7 & 17 \\
\hline Medium & 1669 a & 31 & 41 & 17 & 2108 & 27 & 54 & 17 \\
\hline High & $1801 \mathrm{a}$ & 29 & 46 & 18 & 2361 & 25 & 57 & 18 \\
\hline \multicolumn{9}{|l|}{ Vetch } \\
\hline Low & $293 c$ & 39 & 11 & 11 & 421 & 39 & 16 & 7 \\
\hline Medium & $371 \mathrm{c}$ & 40 & 15 & 11 & 631 & 36 & 25 & 8 \\
\hline High & $419 \mathrm{c}$ & 41 & 14 & 11 & 554 & 38 & 22 & 7 \\
\hline \multicolumn{9}{|c|}{ Year by Species } \\
\hline \multicolumn{9}{|l|}{ Year 1} \\
\hline Rye & 2679 a & $23 c$ & $65 a$ & $23 \mathrm{a}$ & 3850 a & $28 \mathrm{~b}$ & $103 \mathrm{a}$ & $17 \mathrm{a}$ \\
\hline Vetch & $589 \mathrm{~b}$ & $36 \mathrm{~b}$ & $20 \mathrm{~b}$ & $12 \mathrm{~b}$ & $413 \mathrm{~b}$ & $35 \mathrm{a}$ & $15 \mathrm{~b}$ & $5 c$ \\
\hline \multicolumn{9}{|l|}{ Year 2} \\
\hline Rye & $265 b$ & $39 \mathrm{~b}$ & $10 \mathrm{~b}$ & $12 \mathrm{~b}$ & $785 \mathrm{~b}$ & $26 \mathrm{~b}$ & $16 \mathrm{~b}$ & $18 \mathrm{a}$ \\
\hline Vetch & $132 \mathrm{~b}$ & $44 \mathrm{a}$ & $6 \mathrm{~b}$ & $9 c$ & $657 \mathrm{~b}$ & $41 \mathrm{a}$ & $26 \mathrm{~b}$ & $10 \mathrm{~b}$ \\
\hline \multicolumn{9}{|c|}{ Site by Species } \\
\hline \multicolumn{9}{|l|}{ Clay Center } \\
\hline Rye & 1800 & $41 \mathrm{a}$ & $58 \mathrm{a}$ & $12 \mathrm{~b}$ & $1389 \mathrm{~b}$ & $34 \mathrm{a}$ & $48 \mathrm{~b}$ & $14 \mathrm{~b}$ \\
\hline Vetch & 511 & $43 a$ & $18 \mathrm{~b}$ & $11 \mathrm{~b}$ & $164 \mathrm{c}$ & $38 \mathrm{a}$ & $7 d$ & $5 \mathrm{~d}$ \\
\hline \multicolumn{9}{|l|}{ Mead } \\
\hline Rye & 1145 & $21 \mathrm{~b}$ & $17 \mathrm{~b}$ & $22 a$ & $3245 \mathrm{a}$ & $20 \mathrm{~b}$ & $71 \mathrm{a}$ & $21 \mathrm{a}$ \\
\hline Vetch & 210 & $38 \mathrm{a}$ & $8 \mathrm{c}$ & $11 \mathrm{~b}$ & $906 \mathrm{~b}$ & $38 \mathrm{a}$ & $34 \mathrm{c}$ & $10 \mathrm{c}$ \\
\hline
\end{tabular}

\subsection{Cover Crops Planted into Soybean}

At Clay Center, the rate, year by rate, and year by species interactions affected stand counts (Table 3). Seeding rate had a linear effect on stand counts $(p=0.001)$. The year by rate interaction (data not shown) revealed that this was mostly due to linear increases in year 2, from 10 plants $\cdot \mathrm{m}^{-2}$ in the low, to 20 plants $\mathrm{m}^{-2}$ in the medium, and to 39 plants $\mathrm{m}^{-2}$ in the high seeding rates. In year 1 , stand counts were the same, 7,14 , and 14 plants $\mathrm{m}^{-2}$ for the low, medium, and high seeding rates, respectively, which may be in part due to the very low vetch counts in that year (Table 4). The soybean field at Clay Center had been treated with flumioxazin (trade name Valor) for broadleaf weed control which probably inhibited vetch germination. At Mead, which has only year 1 data for fall stand counts, stand counts were greater for rye than for vetch and increasing the seeding rate from low to high increased stand counts in a linear manner $(p=0.009)$. The proportion of cover crop seed that emerged was greater for vetch than for rye at both sites. At Clay Center, three times the number of vetch seeds than rye seeds emerged, and at Mead, twice the number of vetch seeds than rye seeds emerged (Table 4). Biomass and biomass N parameters of cover crops planted into soybean were influenced by cover crop species, the interaction of species and year, and the interaction of species 
and site (Table 5). Rye biomass in year 1 was $3850 \mathrm{~kg} \cdot \mathrm{ha}^{-1}, 3065 \mathrm{~kg} \cdot \mathrm{ha}^{-1}$ more than in year 2 (Table 6). Vetch biomass was the same in each year, on average $535 \mathrm{~kg} \cdot \mathrm{ha}^{-1}$. Across years, rye at Mead was most productive at $3245 \mathrm{~kg} \cdot \mathrm{ha}^{-1}$. Vetch at Clay Center was the least productive cover crop, however, this value was low due to the lack of vetch biomass in 2017. This was not a treatment effect, but rather the consequence of herbicide injury to emerging vetch seedlings (see above). In contrast to cover crops planted into corn, cover crops planted into soybean did not produce greater biomass when seeding rates were increased. Biomass $\mathrm{N}$ concentrations of rye and vetch at Clay Center, and vetch at Mead were similar, ranging from 34 to $38 \mathrm{~g} \cdot \mathrm{kg}^{-1}$, but rye at Mead had only $20 \mathrm{~g} \cdot \mathrm{kg}^{-1}$ (Table 6). Across sites, vetch had greater $\mathrm{N}$ concentrations than rye in each year. Cover crop $\mathrm{N}$ uptake was greater for rye than for vetch, across all other factors. The greatest $\mathrm{N}$ uptake occurred in rye in year 1 with $103 \mathrm{~kg} \mathrm{~N} \cdot \mathrm{ha}^{-1}$. The greatest $\mathrm{N}$ uptake for vetch was at Mead with $34 \mathrm{~kg} \mathrm{~N} \cdot \mathrm{ha}^{-1}$. Despite differences in $\mathrm{N}$ concentration, rye in year 1 had a similar $\mathrm{C} / \mathrm{N}$ ratio to rye in year $2\left(17 \mathrm{~kg} \mathrm{~N} \cdot h \mathrm{~h}^{-1}\right)$. Vetch biomass had lower $\mathrm{C} / \mathrm{N}$ ratios than rye biomass, and vetch $\mathrm{C} / \mathrm{N}$ was lower in year 1 than in year 2 . The $\mathrm{N}$ concentrations, $\mathrm{N}$ uptake, and $\mathrm{C} / \mathrm{N}$ ratios for vetch may be artificially low due to the lack of vetch biomass in year 1 , as mentioned above.

\section{Discussion}

This study investigated the establishment and productivity of rye and vetch broadcast interseeded into no-till corn or soybean stands. We found that 2 to $24 \%$ of rye and 10 to $54 \%$ of vetch seed emerged, likely due to differences in precipitation among sites. Rainfall within one week of cover crop broadcasting was the best predictor for cover crop emergence in a Minnesota study [10]. Mead received more precipitation close to planting than Clay Center (Figures 1 and 2) and had greater stand counts. At Clay Center, in year 2, more rain fell within the week of planting, but only vetch broadcast into corn had greater emergence in year 2 , likely because vetch emergence was inhibited by a residual herbicide in year 1 (see above). Fall counts at Mead were comparable to rye broadcast after corn harvest in no-till systems in Maryland [11] and Kentucky [29], although the Maryland study used higher seeding rates than our study. In Kentucky, the percentage of rye seeds that emerged was $22 \%$ in one year and $64 \%$ in the other year. In another Nebraska study in no-till corn-soybean rotations, $42 \%$ of rye broadcast at $67 \mathrm{~kg} \mathrm{ha}^{-1}$ into corn emerged, resulting in 125 plants $\mathrm{m}^{-2}$ [7]. As in our study, the other authors found that emergence increased after rainfall events, and that broadcast seeds emerged over a longer period than drilled seeds.

Although stand counts of all cover crops increased linearly with seeding rate, only rye cover crops broadcast into corn had a responding increase in biomass. In a study in California in vegetable systems, rye was drilled at 90, 180, and $270 \mathrm{~kg} \cdot \mathrm{ha}^{-1}$, which resulted in stand counts of 272, 526, and 721 plants $\cdot \mathrm{m}^{-2}$ [30]. During early vegetative growth, higher seeding rates had more biomass but fewer tillers than the lower seeding rates. At the onset of the reproductive stage, rye biomass was similar for all seeding rates, probably because rye compensates for lower stand counts by increasing tillering [30]. In our study, varying seeding rates did not increase vetch biomass, possibly because our seeding rates ( 45 to $90 \mathrm{~kg} \cdot \mathrm{ha}^{-1}$ ) were on the higher end. In a study across a range of latitudes in north-eastern states where vetch was drill-planted into tilled fields, maximum vetch biomass was reached when planted at 15 to $20 \mathrm{~kg} \cdot \mathrm{ha}^{-1}$ [31]. In New York and Pennsylvania which are located along similar latitudes to our research stations, vetch biomass increased with higher seeding rates only when planted before 15 September [31]. In our drier climate, it is likely that the available water supports cover crops only at lower seeding rates. Anecdotally, farmers in south-central Nebraska will plant rye cover crops at even lower seeding rates than we did, to conserve soil water. Where more soil water is available such as in irrigated fields, increasing seeding rates could be investigated as a mechanism to maximize cover crop productivity.

Cover crop biomass production depended mostly on species, year, and site influences. Rye planting date was within the range recommended for zone 5. Growing degree accumulation in both years was greater than the $650 \mathrm{GDD}$ needed to produce $1000 \mathrm{~kg} \cdot \mathrm{ha}^{-1}$ of biomass [32], however, a very cold and 
dry spring in year 2 stunted cover crop growth. Interestingly, despite low emergence and fall stand counts, rye productivity was within the range reported from other Nebraska studies that broadcast rye into corn [7] and drill-planted rye after soybean harvest [33] or corn harvest [34]. This suggests that fall stand counts may not predict spring biomass and that broadcast interseeding is an effective method to obtain a productive rye cover crop.

As expected, vetch produced less biomass than rye, but in similar amounts to what was reported from another study at Mead where vetch was broadcast into corn in early September and killed in early May [35]. Vetch produced less than $100 \mathrm{~kg} \cdot \mathrm{ha}^{-1}$ biomass in Iowa, when no-till-drilled after soybean harvest by mid-October and terminated by early May [36]. To achieve at least $1500 \mathrm{~kg} \cdot \mathrm{ha}^{-1}$ of vetch biomass in zone 6a, vetch should be planted by mid-September [37]. In the north-eastern United States, vetch needs to accumulate $926 \mathrm{GDD}$ to produce $4000 \mathrm{~kg} \cdot \mathrm{ha}^{-1}$ of biomass [27]. In our study, we were within the GDD range despite a slightly later planting date, but vetch biomass production was much lower, probably because of insufficient precipitation in our area.

We hypothesized that biomass $\mathrm{N}$ concentration would be greater for vetch, which is a legume, than for rye, a grass, but only rye in year 1 and rye at Mead had lower $\mathrm{N}$ concentrations than vetch in the same year and site. Physiological stage dictates rye biomass $\mathrm{N}$ concentrations, but soil nitrate status also plays a role [38]. At the time of biomass harvest in both years, rye was at Feekes stage 9 except in Clay Center in year 2 where it was terminated at Feekes 4. This could explain the high $\mathrm{N}$ concentrations in rye there. While we did not measure soil N, another study found greater soil nitrate concentrations at Clay Center than at Mead, which could also have caused greater cover crop biomass $\mathrm{N}$ concentrations [7].

The influence of the main crop on broadcast interseeded cover crops was not a factor in the statistical analysis, but we observed differences in the growth of cover crops depending on whether they were planted into corn or soybean. Rye growing in corn had few to no tillers in the fall, and was taller, with a lighter green color (image shown in Figure 3), an indicator of a lack of photosynthetically active radiation [13]. On the other hand, rye growing in soybean had many tillers, short internodes, and dark-green color (image shown in Figure 4). Vetch in soybean also had more leaves and more compact growth than vetch in corn. In the spring, rye and vetch had $57 \%$ and $48 \%$ more biomass, respectively, when planted into soybean than when planted into corn.

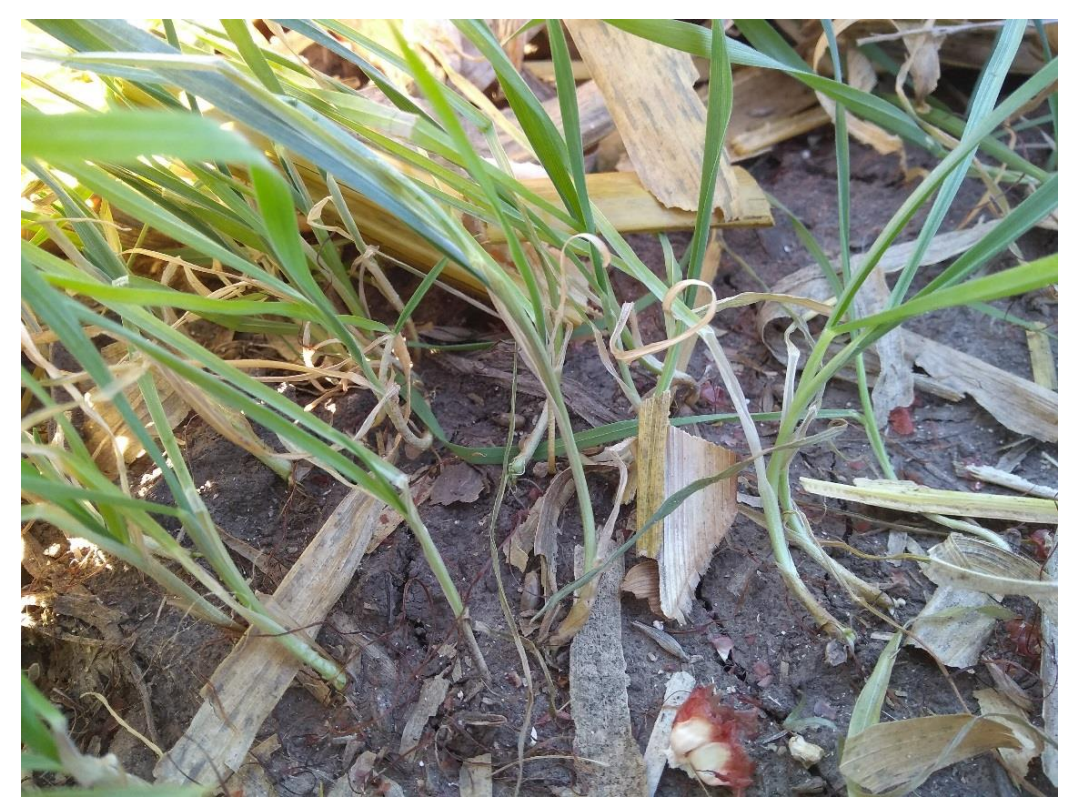

Figure 3. Rye at Mead 70 days after broadcasting into corn. Rye was seeded 19 September; picture was taken 30 November 2017. Note lack of tillers, elongated stems, and light-green color. Corn residue was removed before taking picture. 


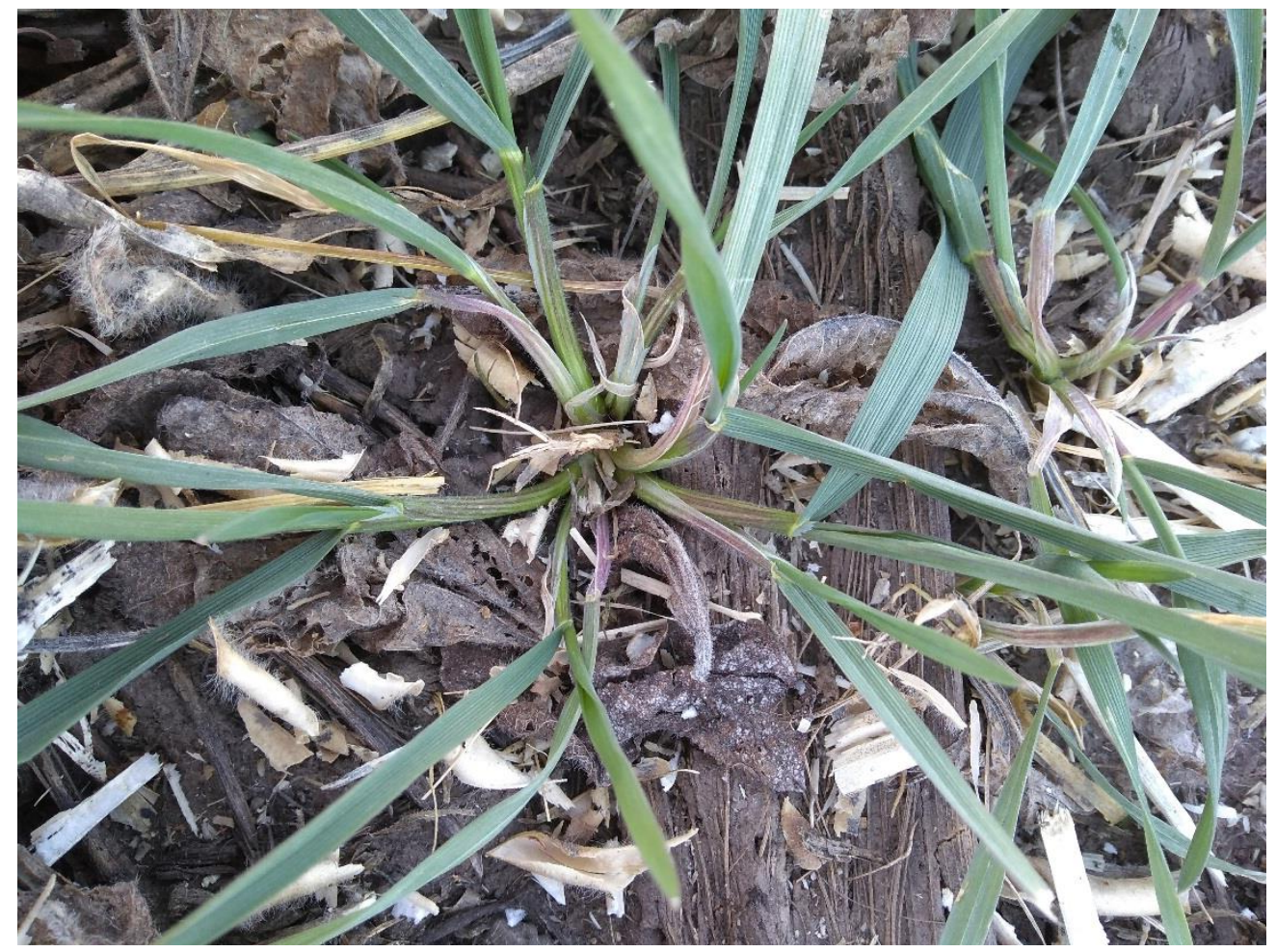

Figure 4. Rye at Mead 70 days after broadcasting into soybean. Rye was seeded 21 September; picture was taken 30 November 2017. Note many tillers, short internodes, and dark-green color.

The crop canopy at broadcasting and the residue left after main crop harvest may have influenced the light interception of broadcast cover crops, soil water, nutrient availability, and temperatures close to the soil surface. Soybean loses most leaves and petioles by R8 [25], increasing cover crop seedlings' access to photosynthetically active radiation which increases the number of tillers in grass species and leaves in non-grass species and could explain the greater number of tillers we observed in rye growing after soybean than after corn (Figures 3 and 4) [14,39]. Greater numbers of fall tillers are associated with greater spring biomass production in rye [40]. On the other hand, in situations where there is less tillering, such as for rye growing in corn residue, increasing the seeding rate may be a way to increase biomass production. Removing corn residue may be another possibility to improve productivity of cover crops but must be weighed against the increased risk of soil erosion [34]. Larger amounts of residue, especially corn stalks, may also be critical in buffering wind speed and chill, which may improve winter survival and subsequent productivity of cover crops in windy and dry sites such as Clay Center (Figure 5).

Nitrogen uptake in rye biomass was highest in year 1 when rye was more productive and reflects rye's $\mathrm{N}$ scavenging ability reported by other authors for drilled rye [41]. Our year 1 values for $\mathrm{N}$ uptake exceed those reported for broadcast rye in Maryland [11]. High $N$ uptake by the rye cover crop can prevent soil nitrate leaching [1,2] which is of interest in areas with high groundwater nitrate concentrations. If rye is managed for $\mathrm{N}$ scavenging after corn, more $\mathrm{N}$ uptake can be achieved if rye seeding rates are increased. In rye after soybean, greater overall $\mathrm{N}$ uptake than after corn was observed, although the main crop effect was not a factor in our study. The greater $\mathrm{N}$ uptake was likely due to greater biomass production, but there may also have been more residual soil $\mathrm{N}$ after soybean. Lower biomass productivity was also the main reason why vetch $\mathrm{N}$ uptake was lower than rye $\mathrm{N}$ uptake. In our study, the most productive vetch was after soybean at Mead, with an $\mathrm{N}$ uptake of $34 \mathrm{~kg} \cdot \mathrm{ha}^{-1}$, but most other sites and years had considerably lower $\mathrm{N}$ uptake. This limits vetch's potential as an $\mathrm{N}$ source for corn in our system, although it should be noted that vetch $\mathrm{N}$ uptake may be greater where it was preceding corn than soybean. However, the high cost of vetch seed, even at the 
lowest seeding rate (Table 2), may be prohibitive to using vetch as an $\mathrm{N}$ source. Dividing cover crop seed cost by cover crop $\mathrm{N}$ uptake in our study (not including cost of planting or killing cover crops), it cost USD 9.5 to produce one $\mathrm{kg}$ of vetch N and USD 0.78 to produce one $\mathrm{kg}$ of rye N. In contrast, it cost USD 0.4 to purchase one $\mathrm{kg}$ of synthetic fertilizer [42]. This illustrates the importance of minimizing seed costs and maximizing cover crop $\mathrm{N}$ uptake if cover crops are to be a viable alternative to synthetic $\mathrm{N}$ fertilizer.

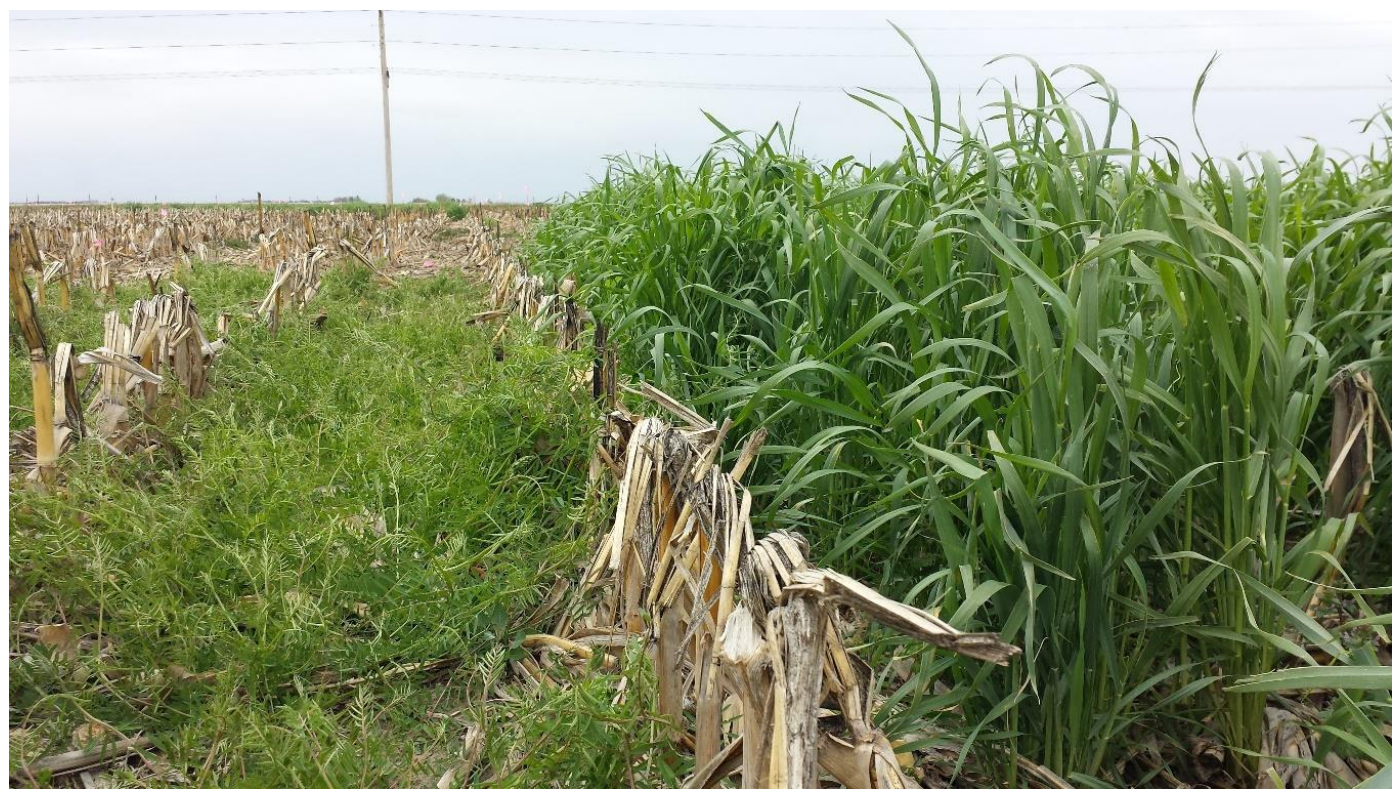

Figure 5. Vetch (left) and rye (right) on 4 May 2017 at Clay Center. Cover crops were broadcast into corn 20 September 2016.

In this study, cover crop effects on soil nutrients and the following corn and soybean crops were not measured, thus it is unclear whether $\mathrm{N}$ uptake resulted in $\mathrm{N}$ supplied to the next crop. Rye decomposition and $\mathrm{N}$ release from decomposing rye residue can be slow and lead to soil $\mathrm{N}$ immobilization within the first four weeks after termination, in turn limiting $\mathrm{N}$ available for main crops planted into rye residue [4]. In our study, rye at Mead and rye in year 1 had the greatest $\mathrm{C} / \mathrm{N}$ ratios, indicating the potential for $\mathrm{N}$ immobilization. In several sites and years, rye $\mathrm{C} / \mathrm{N}$ ratios were as low as vetch $\mathrm{C} / \mathrm{N}$ ratios, and rye residues were likely to mineralize quickly, possibly supplying $\mathrm{N}$ to the next crop $[4,5]$.

\section{Conclusions}

This study demonstrated that increasing seeding rates of cover crops broadcast interseeded into no-till corn or soybean systems in the western Corn Belt increases fall plant populations but has limited effects on cover crop spring biomass production. Only rye planted into corn responded to an increase in seeding rates with greater biomass and $\mathrm{N}$ uptake. Despite low seed emergence, broadcast interseeded rye cover crops can be productive, making them a good cover crop to reduce soil $\mathrm{N}$ leaching losses. Vetch cover crop biomass and $\mathrm{N}$ uptake were low, likely due to the limited amount of GDD and precipitation during the cover crop growing season in the western Corn Belt.

Future research should focus on improving seed germination of broadcast interseeded cover crops, such as investigating seed polymer coatings and cover crop irrigation. Improved germination could reduce the amount of seed necessary to establish a productive stand, reducing cover crop seed costs. In addition, management strategies that increase cover crop biomass production and $\mathrm{N}$ uptake, such as extending the growing season by planting earlier and terminating later, deserve more research efforts. It is also essential that we better understand the physiological responses of cover crops grown in the shade of main crops and residue to select those species or cultivars that tolerate low-light conditions. 
While GDD requirements of cover crops have been relatively well documented in the literature and corresponding planting date recommendations have been established, little information is available on the precipitation requirements of cover crops. In the western Corn Belt, available precipitation may be more limiting to cover crop growth than GDD accumulation and may require more drought-tolerant cover crop cultivars and species.

Author Contributions: Conceptualization, K.K.-C.; methodology, K.K.-C.; formal analysis, K.K.-C.; investigation, K.K.-C.; writing-original draft preparation, K.K.-C.; writing-review and editing, K.K.-C. and R.W.E.; project administration, K.K.-C.; funding acquisition, K.K.-C. and R.W.E. Both authors have read and agreed to the published version of the manuscript.

Funding: This research was funded by the Nebraska Corn Board, grant number 88-R-1617-11, and the Nebraska Soybean Board, grant number 1709.

Acknowledgments: We thank Tom Galusha and George Biliarski for technical support in implementing the experiments.

Conflicts of Interest: The authors declare no conflict of interest. The funders had no role in the design of the study; in the collection, analyses, or interpretation of data; in the writing of the manuscript, or in the decision to publish the results.

\section{References}

1. Finney, D.M.; White, C.M.; Kaye, J.P. Biomass Production and Carbon/Nitrogen Ratio Influence Ecosystem Services from Cover Crop Mixtures. Agron. J. 2016, 108, 39-52. [CrossRef]

2. Thapa, R.; Mirsky, S.B.; Tully, K.L. Cover Crops Reduce Nitrate Leaching in Agroecosystems: A Global Meta-Analysis. J. Environ. Qual. 2018, 47, 1400-1411. [CrossRef] [PubMed]

3. Perrone, S.; Grossman, J.; Liebman, A.; Sooksa-nguan, T.; Gutknecht, J. Nitrogen Fixation and Productivity of Winter Annual Legume Cover Crops in Upper Midwest Organic Cropping Systems. Nutr. Cycl. Agroecosys. 2020, 117, 61-76. [CrossRef]

4. Sievers, T.; Cook, R.L. Aboveground and Root Decomposition of Cereal Rye and Hairy Vetch Cover Crops. Soil Sci. Soc. Am. J. 2018, 82, 147-155. [CrossRef]

5. Lacey, C.; Armstrong, S. The Efficacy of Winter Cover Crops to Stabilize Soil Inorganic Nitrogen after Fall-Applied Anhydrous Ammonia. J. Env. Qual. 2015, 44, 442-448. [CrossRef]

6. Wilson, M.L.; Allan, D.L.; Baker, J.M. Aerially Seeding Cover Crops in the Northern US Corn Belt: Limitations, Future Research Needs, and Alternative Practices. J. Soil Water Cons. 2014, 69, 67A-72A. [CrossRef]

7. Koehler-Cole, K.; Elmore, R.W.; Blanco-Canqui, H.; Francis, C.A.; Shapiro, C.A.; Proctor, C.A.; Ruis, S.J.; Heeren, D.M.; Irmak, S.; Ferguson, R.B. Cover Crop Productivity and Subsequent Soybean Yield in the Western Corn Belt. Agron. J. 2020, 112, 2649-2663. [CrossRef]

8. Oliveira, M.C.; Butts, L.; Werle, R. Assessment of Cover Crop Management Strategies in Nebraska, US. Agriculture 2019, 9, 124. [CrossRef]

9. Wuest, S.B.; Albrecht, S.L.; Skirvin, K.W. Vapor Transport vs. Seed-Soil Contact in Wheat Germination. Agron. J. 1999, 91, 783-787. [CrossRef]

10. Wilson, M.L.; Baker, J.M.; Allan, D.L. Factors Affecting Successful Establishment of Aerially Seeded Winter Rye. Agron. J. 2013, 105, 1868-1877. [CrossRef]

11. Fisher, K.A.; Momen, B.; Kratochvil, R.J. Is Broadcasting Seed an Effective Winter Cover Crop Planting Method? Agron. J. 2011, 103, 472. [CrossRef]

12. Noland, R.L.; Wells, M.S.; Sheaffer, C.C.; Baker, J.M.; Martinson, K.L.; Coulter, J.A. Establishment and Function of Cover Crops Interseeded into Corn. Crop Sci. 2018, 58, 863. [CrossRef]

13. Fiorucci, A.-S.; Fankhauser, C. Plant Strategies for Enhancing Access to Sunlight. Curr. Biol. 2017, 27, R931-R940. [CrossRef]

14. Brainard, D.C.; Bellinder, R.R.; DiTommaso, A. Effects of Canopy Shade on the Morphology, Phenology, and Seed Characteristics of Powell Amaranth (Amaranthus Powellii). Weed Sci. 2005, 53, 175-186. [CrossRef]

15. Belfry, K.D.; Van Eerd, L.L. Establishment and Impact of Cover Crops Intersown into Corn. Crop Sci. 2016, 56, 1245-1256. [CrossRef]

16. Midwest Cover Crops Council. Cover Crop Recipes. Available online: http://mccc.msu.edu/ (accessed on 12 September 2020). 
17. Natural Resources Conservation Service. USDA. Plant Guide and Fact Sheets. 2012. Available online: https://plants.usda.gov/java/factSheet (accessed on 4 March 2019).

18. Clark, A. Managing Cover Crops Profitably, 3rd ed.; Diane Publishing, Sustainable Agriculture Network: Beltsville, MD, USA, 2007.

19. Blanco-Canqui, H.; Wortmann, C. Crop Residue Removal and Soil Erosion by Wind. J. Soil Water Cons. 2017, 72, 97A-104A. [CrossRef]

20. Sauer, T.J.; Hatfield, J.L.; Prueger, J.H. Corn Residue Age and Placement Effects on Evaporation and Soil Thermal Regime. Soil Sci. Soc. Am. J. 1996, 60, 1558-1564. [CrossRef]

21. Rudnick, D.; Irmak, S.; Ferguson, R.; Shaver, T.; Djaman, K.; Slater, G.; Bereuter, A.; Ward, N.; Francis, D.; Schmer, M.; et al. Economic Return versus Crop Water Productivity of Maize for Various Nitrogen Rates under Full Irrigation, Limited Irrigation, and Rainfed Settings in South Central Nebraska. J. Irrig. Drain. Eng. 2016, 142, 04016017. [CrossRef]

22. Shapiro, C.A.; Wortmann, C.S. Corn Response to Nitrogen Rate, Row Spacing, and Plant Density in Eastern Nebraska. Agron. J. 2006, 98, 529-535. [CrossRef]

23. Elmore, R.W. Soybean Cultivar Responses to Row Spacing and Seeding Rates in Rainfed and Irrigated Environments. J. Prod. Agric. 1998, 11, 326-331. [CrossRef]

24. Abendroth, L.J.; Elmore, R.W.; Boyer, M.J.; Marlay, S.K. Corn Growth and Development; Iowa State University Extension: Ames, IA, USA, 2011; PMR 1009.

25. Pedersen, P.; Licht, M. Soybean Growth and Development; PM 1945; Iowa State University Extension: Ames, IA, USA, 2014.

26. Miller, R.O.; Kotuby-Amacher, J.; Rodriguez, J.B. Total Nitrogen in Botanical Materials-Automated Combustion Method. In Western States Laboratory Proficiency Testing Program. Soil and Plant Analytical Methods; Version 4.00; Western States-NAPT Program: Fort Collins, CO, USA, 1997; pp. 106-107.

27. Teasdale, J.R.; Devine, T.E.; Mosjidis, J.A.; Bellinder, R.R.; Beste, C.E. Growth and Development of Hairy Vetch Cultivars in the Northeastern United States as Influenced by Planting and Harvesting Date. Agron. J. 2004, 96, 1266-1271. [CrossRef]

28. Stannard, M.; Brunty, J.; Pan, D.B. Planting Dates for Fall Cover Crops in the Irrigated Columbia Basin; US Department of Agriculture Natural Resources Conservation Service: Spokane, WA, USA, 2020.

29. Haramoto, E.R. Species, Seeding Rate, and Planting Method Influence Cover Crop Services Prior To Soybean. Agron. J. 2019, 111, 1068. [CrossRef]

30. Boyd, N.S.; Brennan, E.B.; Smith, R.F.; Yokota, R. Effect of Seeding Rate and Planting Arrangement on Rye Cover Crop and Weed Growth. Agron. J. 2009, 101, 47-51. [CrossRef]

31. Mirsky, S.B.; Ackroyd, V.J.; Cordeau, S.; Curran, W.S.; Hashemi, M.; Reberg-Horton, S.C.; Ryan, M.R.; Spargo, J.T. Hairy Vetch Biomass across the Eastern United States: Effects of Latitude, Seeding Rate and Date, and Termination Timing. Agron. J. 2017, 109, 1510. [CrossRef]

32. Farsad, A.; Randhir, T.O.; Herbert, S.J.; Hashemi, M. Spatial Modeling of Critical Planting Date for Winter Rye Cover Crop to Enhance Nutrient Recovery. Agron. J. 2011, 103, 1252-1257. [CrossRef]

33. Kessavalou, A.; Walters, D.T. Winter Rye as a Cover Crop Following Soybean under Conservation Tillage. Agron. J. 1997, 89, 68-74. [CrossRef]

34. Ruis, S.J.; Blanco-Canqui, H.; Jasa, P.J.; Ferguson, R.B.; Slater, G. Can Cover Crop Use Allow Increased Levels of Corn Residue Removal for Biofuel in Irrigated and Rainfed Systems? Bioenergy Res. 2017, 10, 992-1004. [CrossRef]

35. Power, J.F.; Doran, J.W.; Koerner, P.T. Hairy Vetch as a Winter Cover Crop for Dryland Corn Production. J. Prod. Agric. 1991, 4, 62-67. [CrossRef]

36. Appelgate, S.R.; Lenssen, A.W.; Wiedenhoeft, M.H.; Kaspar, T.C. Cover Crop Options and Mixes for Upper Midwest Corn-Soybean Systems. Agron. J. 2017, 109, 968. [CrossRef]

37. Duiker, S.W. Establishment and Termination Dates Affect Fall-Established Cover Crops. Agron. J. 2014, 106, 670-678. [CrossRef]

38. Ruffo, M.L.; Bollero, G.A. Modeling Rye and Hairy Vetch Residue Decomposition as a Function of Degree-Days and Decomposition-Days. Agron. J. 2003, 95, 900. [CrossRef]

39. Evers, J.B.; Vos, J.; Andrieu, B.; Struik, P.C. Cessation of Tillering in Spring Wheat in Relation to Light Interception and Red: Far-Red Ratio. Ann. Bot. 2006, 97, 649-658. [CrossRef] 
40. Baron, V.S.; Dick, A.C.; Salmon, D.F.; McLeod, J.G. Fall Seeding Date and Species Effects on Spring Forage Yield of Winter Cereals. J. Prod. Agric. 1999, 12, 110-115. [CrossRef]

41. Brennan, E.B.; Boyd, N.S. Winter Cover Crop Seeding Rate and Variety Affects during Eight Years of Organic Vegetables: I. Cover Crop Biomass Production. Agron. J. 2012, 104, 684. [CrossRef]

42. Klein, R.; McClure, G. Nebraska Crop Budgets. 2020 Crop Budgets. University of Nebraska-Lincoln. Available online: https://cropwatch.unl.edu/budgets (accessed on 21 September 2020).

Publisher's Note: MDPI stays neutral with regard to jurisdictional claims in published maps and institutional affiliations.

(C) 2020 by the authors. Licensee MDPI, Basel, Switzerland. This article is an open access article distributed under the terms and conditions of the Creative Commons Attribution (CC BY) license (http://creativecommons.org/licenses/by/4.0/). 